\title{
Ārstniecības personas tiesības uz reliǵiskās pārliecības brīvību un to ìstenošana, sniedzot veselības aprūpes pakalpojumus Latvijā: konstitucionālās aizsardzības ietvars
}

\author{
Dr. iur. Laura Šāberte \\ Rīgas Stradiṇa universitāte, Juridiskā fakultāte, Latvija \\ sabertelaura@inbox.lv
}

\section{Kopsavilkums}

Pētījums ir par ārstniecības personas tiesībām uz reliǵiskās pārliecības brīvību konstitucionālās aizsardzības aspektu kontekstā ar Latvijas Republikas starptautiskajām saistībām.

Lai izzinātu ārstniecības personas relig̣iskās pārliecības brīvības īstenošanas robežas, sniedzot veselības aprūpes pakalpojumus, ir jāiepazīstas ar Latvijas Republikas Satversmes 99. panta saturu par ārstniecības personas reliǵgiskās pārliecības brīvības konstitucionālo aizsardzību un jāizpēta Eiropas Cilvēktiesību tiesas un Eiropas Savienības tiesas praksē paustās atziṇas. Pamatojoties uz izzinātajiem problēmjautājumiem, rakstā tiek norādīti nepieciešamie pētniecības virzieni ārstniecības personu tiesību attīstībai Latvijas Republikā.

Atslēgvārdi: ārstniecības persona, pacients, veselības aprūpe, veselības aprūpes pakalpojums, reliğiskās pārliecības brīvība, konstitucionālā aizsardzība.

\section{levads}

Ārstniecības personas religíiskās pārliecības brīvība Latvijas Republikā (turpmāk Latvijā) tiek aizsargāta ar Latvijas Republikas Satversmes (turpmāk - Satversmes) 99. pantu, kura pirmajā teikumā ${ }^{1}$ noteikts, ka "ikvienam ir tiesības uz domas, apziṇas un reliǵiskās pārliecības brīvību" [21].

${ }^{1}$ Rakstā netiek veikts pētījums par Satversmes 99. panta otrajā teikumā nostiprināto baznīcas atdalīīibu no valsts; pētijums tiek veikts tikai par vienu no Satversmes 99. panta pirmajā dal̦ā nostiprinātajām brīvībām - reliǵiskās pārliecības brīvību, kas izriet no starptautiskajiem cilvēktiesību dokumentiem. 
Laura Šāberte. Ārstniecības personas tiesības uz religiskās pārliecības brīvību un to īstenošana, sniedzot veselības aprūpes pakalpojumus Latvijā: konstitucionālās aizsardzības ietvars

Domas, apziṇas un religiskās pārliecības brīvība [19] ir pirmās paaudzes cilvēktiesības $[28,6]$, kas nostiprinātas vairākos nozīmīgos starptautiskos cilvēktiesību dokumentos, piemēram, Vispārējās cilvēktiesību deklarācijas (turpmāk - Cilvēktiesību deklarācija) 18. pantā [31], Starptautiskā pakta par pilsoṇu un politiskajām tiesībām (turpmāk - Pakts) 18. pantā [29], Eiropas Cilvēktiesību un pamatbrīvību aizsardzības konvencijas (turpmāk - ECPAK) 9. pantā [6], kā arī Eiropas Savienības Pamattiesību hartas (turpmāk - Pamattiesību harta) 10. pantā [14]. Dalībvalstīm, kurām ir saistoši minētie cilvēktiesību dokumenti, kas aizsargā domas, apziṇas un religíiskās pārliecības brīvību, tostarp arī Latvijai, ir pienākums nodrošināt cilvēktiesību efektīvu aizsardzību.

Ievērojot to, ka Latvijas tiesību sistēmai ir raksturīga atvērtība starptautiskajām tiesībām [24], un to, ka saskaṇā ar Satversmes 89. pantu Latvijā tiek atzīstas un aizsargātas cilvēka pamattiesības saskaṇā ar Satversmi, likumiem un Latvijai saistošiem starptautiskajiem līgumiem, šì raksta mērkis ir konstitucionālās aizsardzības satura izpēte attiecībā uz ārstniecības personas tiesībām īstenot Satversmes 99. pantā nostiprināto reliǵiskās pārliecības brīvību, pildot darba pienākumus jeb sniedzot veselības aprūpes pakalpojumus Latvijā, kontekstā ar Latvijas starptautiskajām saistībām. Publikācijas mērḳis ir arī turpmāko pētniecības virzienu šajā jautājumā norādī̌̌ana. ${ }^{2}$

Lai sasniegtu izvirzīto mērḳi, rakstā tiek izklāstīts Satversmes 99. panta saturs par ārstniecības personas reliǵiskās pārliecības brīvības konstitucionālo aizsardzību, un, analizējot Eiropas Cilvēktiesību tiesas (turpmāk - ECT) un Eiropas Savienības Tiesas (turpmāk - EST) praksē paustās atziṇas par ārstniecības personas religiskās pārliecības brīvības îstenošanas robežām, sniedzot veselības aprūpes pakalpojumus, tiek izpētīta ar Satversmes 99. pantu aizsargātās religiskās pārliecības brīvības interpretācija.

Raksta temata un pētniecības aktualitāti, pirmkārt, iezīmē apstāklis, ka mūsdienās migrācijas pieaugošo tendenču dẹl pastiprināta uzmanība jāsāk pievērst daudzām jaunām, Latvijai neraksturīgām reliǵijām, piemēram, islāmam, un nepieciešama padziḷināta ārstniecības personas tiesību uz reliǵiskās pārliecības brīvību izpēte. Gan pacientiem,

2 Tiesību zinātnieku un Eiropas Cilvēktiesību tiesas atziṇās nereti jēdzienā "relig̣ijas brīvība” tiek ietverta arī "domas brīvība" un "apziṇas brīvība". Saskaṇā ar ārstniecības personu darbības specifiku "domas brīvībai”' un "apziṇas brīvībai” būtu nepieciešams veltìt atsevišḳus, padziḷinātus pētījumus, piemēram, par ārstniecības personas tiesībām uz viedokli par alternatīvo medicīnu (sk., piemēram, Eiropas Cilvēktiesību tiesas 1998. gada 15. janvāra spriedumu lietā Nyyssönen vs. Finland. Pieteikuma Nr. 30406/96). Rakstā veikta tikai religisiskās pārliecības brīvības konstitucionālās aizsardzības izpēte. Tāpat publikācijā apzināti tiek izmantots Satversmē nostiprinātais termins "relig̣iskās pārliecības brīvība", ar ko jāsaprot arī "ticības brīvība" un "religijas brīvība". Satversmes 99. pantā ir nostiprināts termins "religisiskās pārliecības brīvība", turpretī starptautiskajos cilvēktiesību dokumentos šis termins tiek lietots plašākā nozīmē - "reliǵijas brīvība", kura detalizēts saturs atklāts katra starptautiskā cilvēktiesību dokumenta individuālā tiesību normā, lietojot gan "relig̣iskās pārliecības", gan "relig̣iskās ticības" terminus. Rakstā tiek ievēroti terminu "reliǵija", "ticība", "neticīgs" un "pārliecība" izpratne latviešu valodā (sk. 5., 19., 21., 31. avotu literatūras sarakstā). 
Laura Šāberte. Ārstniecības personas tiesības uz religigiskās pārliecības brīvību un to īstenošana, sniedzot veselības aprūpes pakalpojumus Latvijā: konstitucionālās aizsardzības ietvars

gan ārstniecības personām ir tiesības uz religiskās pārliecības brīvību, un nepieciešams noskaidrot, kā šo brīvību sabalansēti îstenot, neaizskarot nevienu no pusēm.

Otrkārt, izvēlētā temata aktualitāti pamato nepietiekama ar ārstniecības personu tiesībām saistītu jautājumu pētniecība Latvijā. Šobrīd normatīvais regulējums Latvijā primāri aizsargā pacientu tiesības, savukārt ārstniecības personu tiesības šajā sarežğìtajā procesā tiek atstātas atvērtai juridiskai diskusijai, kas nereti rodas gadījumos, kad pastāv strīds par pacienta dzīvībai vai veselībai potenciāli nodarīto kaitējumu.

Treškārt, izvēlētā temata aktualitāti raksturo valsts loma dažādu reliǵiju līdzāspastāvēšanas organizēšanā, kur, no vienas puses, religiskās pārliecības brīvība cilvēktiesību līmenī tiek garantēta katram sabiedrības indivīdam, bet, no otras puses, aizvien aktuāls ir jautājums, kā šì brīiviba var tikt savienota ar ārstniecības personas profesionālo darbību un tās unikalitāti pacientu tiesību kontekstā.

Rakstā veikta normatīvo aktu, tiesu prakses un zinātniskās literatūras izpēte, izmantojot deskriptīvo (aprakstošo), analītisko un deduktīvo pētniecības metodi. Ar deskriptīvās metodes palīdzību tiek atklāts pētāmo normatīvo aktu, tiesību zinātņu literatūras, zinātnisko rakstu, tiesu prakses un citu avotu saturs, ar analïtisko metodi analizēts avotu saturs un pamatota turpmāko pētījumu veikšanas nepieciešamība, kā arī ilustrētas normatīvā regulējuma attīstības perspektīvas. Savukārt ar deduktīvo metodi no vispārējām tēzēm izdarīti konkrēti secinājumi, kuri atspoguḷoti raksta nobeigumā.

\section{Ārstniecības personas tiesības īstenot reliǵiskās pārliecības brīvību: konstitucionālās aizsardzības saturs}

Satversmes 99. pants Latvijā konstitucionālā līmenī aizsargā ikviena sabiedrības indivīda tiesības uz religisiskās pārliecības brīvību [21], kas ietver dažādus religiskus, nereliğiskus un ateistiskus uzskatus, kā arī tiesības pien,emt reliǵiju vai izvēlēties nepiederēt ne pie vienas religíijas. Religiskās pārliecības brīvība ir pamatelements ne tikai ticīgo identitātes un dzìves uzskatu veidošanā, bet vienlaikus tā ir arī vērtība ateistiem, agnostiḳiem, skeptiḳiem un nepārliecinātajiem [5, 334]. Reliǵiskās pārliecības brīvība ietver ne tikai tiesības ticēt un praktizēt ticību (pozitīvā religisiskā brīvība), bet arī tiesības neticēt un nepraktizēt ticību (negatīvā religisisā brīiviba) [23]. Ievērojot religisko plurālismu demokrātiskā sabiedrībā, valstij ir ḷoti nozīmīga loma dažādu reliǵiju līdzāspastāvēšanas organizēšanā, izstrādājot atbilstošus normatīvos aktus un nodrošinot dažādu religíisku grupu savstarpēju toleranci un iecietību [5, 334]. Šĩ dažādo reliǵiju līdzāspastāvēšanas organizēšana, nodrošinot reliǵiskās pārliecības brīvības konstitucionālo aizsardzību, ir aktuāla arī veselības aprūpes nozarē.

Veselïbas aprūpes nozarē gan pacientam, kurš vēršas pēc veselības aprūpes pakalpojumiem vai saņem šos pakalpojumus $[3,1$. panta 11. punkts], gan ārstniecības personai, kura sniedz veselïbas aprūpes pakalpojumus pacientam $[30,198]$, ir tiesības uz relig̣iskās pārliecības brīvību. Reliğiskās pārliecības brīvība ietver tiesības īstenot savu 
Laura Šāberte. Ārstniecības personas tiesības uz religiskās pārliecības brīvību un to īstenošana, sniedzot veselības aprūpes pakalpojumus Latvijā: konstitucionālās aizsardzības ietvars

ticību, ne tikai atrodoties vienatnē savā privātajā teritorijā, bet arī atrodoties kopā ar citiem publiskā telpā [5, 336]. Arī ārstniecības personai ir tiesības uz relig̣iskās pārliecības brīvību vienatnē, sniedzot veselības aprūpes pakalpojumus pacientam un arī atrodoties vienā telpā ar citām personām ārstniecības iestādē - kolēgiem, ārstniecības personām un pacienta tuviniekiem -, rezultātā starp šīm personām var izveidoties interešu sadursme atškirīīgu religiisku uzskatu dēḷ.

Religiiskā plurālisma ietvaros valstij ir jāspēj nodrošināt reliǵiskās pārliecības brīvības konstitucionālo aizsardzību, neaizskarot nevienu no pusēm. Satversmes 99. pants aizsargā religiskās pārliecības brīiỉbu tās iekšējā aspekta (forum internum) un ārējā aspekta (forum externum) formā, kas iezīmē religiskās pārliecības brīvības ìstenošanas robežas.

Religíiskās pārliecības brīivibas īstenošanas iekšējais aspekts, kas raksturojams kā neaktīvs un intraverts, individuāls un dziḷi personisks pārdzīvojums, ticot pārdabiskiem, pārcilvēciskiem spēkiem [5, 332], ir absolūta tiesība, un tas aizsargājams tādējādi, ka dalïbvalstīm, kurām saistoši ir rakstā iepriekš minētie cilvēktiesību dokumenti, nav tiesību iejaukties un veikt piespiedu pasākumus, lai šos uzskatus mainītu [7]. Piemēram, valsts nedrīkst atzìt par leǵitīmu tādu ārstniecības iestādes kā ārstniecības personas darba devēja rīcību, ar kuru ārstniecības persona ir tikusi piespiesta mainìt reliǵisko pārliecību, lai tā varētu turpināt darba tiesiskās attiecības ārstniecības iestādē.

Religiskās pārliecības brīvības īstenošanas ārējais aspekts (piemēram, religisku simbolu izmantošana, brīvdienu un atpūtas dienu ievērošana, ěšanas noteikumu ievērošana, atšḳirīga apgérba vai galvassegas valkāšana, neticības paušana $)^{3}$ [1] izpaužas ārējas un aktīvas manifestācijas formā $[5,334]$ un var tikt ierobežots, pastāvot noteikti pierādāmiem apstākḷiem, kas izriet no Satversmes 116. panta un Latvijas starptautiskajām saistībām cilvēktiesību jomā.

Satversmes 116. pantā paredzēts ierobežot "reliğiskās pārliecības paušanu" gadījumos, kad nepieciešams aizsargāt citu cilvēku tiesības, demokrātisko valsts iekārtu, sabiedrības drošỉbu, labklājību un tikumību [21]. Tātad relig̣iskās pārliecības paušanu var ierobežot tikai tajos gadījumos, ja nepieciešams aizsargāt sabiedrību un

${ }^{3}$ Administratīvās apgabaltiesas 2011. gada 2. decembra spriedums lietā Nr. A42446907 (AA433165-11/18). Administratīvā apgabaltiesa izdarījusi atsauci uz Starptautiskā pakta par pilsoniskajām un politiskajām tiesībām izveidotās Cilvēktiesību komitejas 1993. gada 30. jūlija vispārīgo komentāru Nr. 22.

${ }^{4}$ Latvijas Republikas Satversmē nav dots jēdziena "religiskās pārliecības paušana" skaidrojums, savukārt ECPAK 9. pantā un Pakta 18. pantā norādīts, ka religisisās pārliecības paušana ietver kultu piekopšanu, religisisku un rituālu ceremoniju izpildīšanu un mācību sludināšanu. Apvienoto Nāciju Organizācijas Cilvēktiesību komiteja atzinusi, ka reliǵiskās pārliecības paušana ietver arī reliǵisko priekšmetu lietošanu; ar to jāsaprot religiskās pārliecības brīvības ārējais aspekts (sk. avotu literatūras sarakstā [6]; par šo jautājumu seminārā Pavasara aktualitātes nozarē un papildjautājumi (kurss Medicīnas darbinieku un pacientu tiesību aizsardzības aktuālās problēmas) Rīgas Stradiṇa universitātē 2017. gadā uzstājās S. Slokenberga. 
Laura Šāberte. Ārstniecības personas tiesības uz religiskās pārliecības brīvību un to īstenošana, sniedzot veselības aprūpes pakalpojumus Latvijā: konstitucionālās aizsardzības ietvars

konstitucionālas vērtības. Piemēram, ar religisisko pārliecību nevar attaisnot ārstniecības personas profesionālo pienākumu tîšu nepildīšanu, apzināti nodarot kaitējumu pacienta dzīiībai (šāda rīcība ir atzīstama par noziedzīgu nodarījumu). Satversmes 116. pantā nav paredzēts, kā tieši ierobežojama religisiskās pārliecības paušana un ko tā ietver, tomēr tas ir izsecināms no turpmāk analizētajiem starptautiskajiem cilvēktiesību instrumentiem, kuri aizsargā relig̣iskās pārliecības brīvību. Veicot ārstniecības personas tiesību uz reliǵiskās pārliecības brīvību konstitucionālās aizsardzības analīzi kontekstā ar starptautiskajiem cilvēktiesību instrumentiem, ir nosakāmas relig̣iskās pārliecības brīvības īstenošanas robežas.

\section{Ārstniecības personas tiesïbas ìstenot reliǵiskās pārliecības brīvību: konstitucionālās aizsardzības analīze}

Saskaṇā ar Satversmes 89. pantu Latvija atzīst un aizsargā cilvēka pamattiesības atbilstīgi Satversmei, likumiem un Latvijai saistošiem starptautiskajiem līgumiem [21]. Ar Satversmes 99. pantu aizsargātās ārstniecības personas tiesības uz relig̣iskās pārliecības brīvību ir interpretējamas kontekstā ar Latvijas starptautiskajām saistībām cilvēktiesību jomā. Dalībvalstīm, tostarp Latvijai, kuras pievienojušās starptautiskajiem cilvēktiesību instrumentiem, kuri aizsargā religiskās pārliecības brīvību kā nozīmīgu pamatvērtību, ir pienākums izstrādāt normatīvos aktus, lai šīs cilvēktiesības tiktu efektīvi aizsargātas. ECPAK preambulā ir skaidri noteikts, ka dalībvalstis vienojas ievērot ECPAK ietvertās cilvēktiesības atbilstīgi Cilvēktiesību deklarācijai un tam, ka tā paredz nodrošināt vispārēju un efektīvu tajā deklarēto tiesību atzǐšanu un ievērošanu [6].

Latvijas starptautiskās saistības relig̣iskās pārliecības brīvības aizsardzībā ir nostiprinātas vairākos nozīmīgos starptautiskos cilvēktiesību instrumentos, piemēram, Cilvēktiesību deklarācijas 18. pantā [31], Pakta 18. pantā [29], ECPAK 9. pantā [6], kā arī Pamattiesību hartas 10. pantā [14]. Šie cilvēktiesību instrumenti aizsargā ikviena indivīda tiesības uz reliǵiskās pārliecības brīvību, ietverot tiesības brīvi mainīt savu reliǵisko pārliecību un nodoties tai kā vienatnē, tā kopā ar citiem, publiski vai privāti, piekopjot kultu, izpildot religiskas vai rituālas ceremonijas, kā arī sludinot mācību. Turklāt cilvēktiesību instrumenti aizliedz pakḷaut indivīdu piespiešanai, kas var mazināt relig̣iskās pārliecības brīvību. Vienlaikus cilvēktiesību instrumenti paredz, ka reliǵijas brīvība sastāv no diviem elementiem - iekšējās ticības, kas ir absolūta tiesība, jo katram ir tiesības ticēt vai neticēt, kam vien tas vēlas, un religiskās pārliecỉbas paušanas, kas nav absolūta tiesība, jo tā var tikt ierobežota sabiedrības aizsardzības nolūkos [20]. Papildus tam, kā tas noteikts Satversmes 116. pantā, ECPAK un Pakts skaidri nosaka, ka brīvība nodoties religíiskajai pārliecībai, ar ko jāsaprot reliǵiskās pārliecības paušana, var tikt ierobežota arī sabiedriskās kārtības un veselības aizsardzības nolūkos [6, 9. pants; 29, 18. pants], kas jo īpaši svarīgi ir pacienta tiesību aizsardzỉbas kontekstā. Latvijā saskaṇā ar Pacientu tiesību likuma 5. panta otro daḷu (turpmāk - PTL) pacientam ir tiesības uz kvalitatīvu 
Laura Šāberte. Ārstniecības personas tiesības uz religiskās pārliecības brīvību un to īstenošana, sniedzot veselības aprūpes pakalpojumus Latvijā: konstitucionālās aizsardzības ietvars

un kvalificētu veselības aprūpi [26], kas ietver pacienta tiesības uz veselības aizsardzību veselības aprūpes procesā. Lìdz ar to ārstniecības personas religiskās pārliecības paušanu saskaṇā ar Satversmes 116. pantu var ierobežot, lai aizsargātu pacienta tiesības uz kvalitatīvu un kvalificētu veselïbas aprūpi.

Starptautisko cilvēktiesību instrumentu kontekstā, vērtējot līdzsvaru starp indivīda pamattiesību ierobežojumu un labumu, ko iegūst sabiedrība šì ierobežojuma gadījumā, ir jāizskata arī diskriminācijas aizlieguma principu ievērošana, jo reliǵiskā pārliecība var būt diskriminācijas iemesls [5, 326]. Tas var būt, piemēram, gadījumos, kad jāizvērtē darba devēja uzteikums darbiniekam un iespējamie diskriminācijas aizlieguma principa pārkāpumi darba devēja un darbinieka religiskās pārliecības uzskatu dēl. ${ }^{5}$ Tādējādi, ievērojot, ka ārstniecības persona, sniedzot veselības aprūpes pakalpojumus, pilda darba pienākumus, būtiska nozīme religíiskās pārliecības brīvības aizsardzības interpretācijā ir ne tikai ECT paustajām atziṇām attiecỉbā uz ECPAK 9. pantu, bet arī EST praksē paustajām atziṇām attiecībā uz Eiropas Savienības Padomes 2000. gada 27. novembra Direktīvu 2000/78/EK, kas nosaka kopēju sistēmu vienlīdzīgai attieksmei pret nodarbinātību un profesiju (turpmāk - Direktīva Nr. 2000/78/EK), tajā ietvertajām tiesību normām, kas paredz diskriminācijas aizliegumu.

${ }^{5}$ Diskriminācijas aizliegums Latvijā tiek garantēts ar Satversmes 91. pantu (sk. 21. avotu literatūras sarakstā). Vienlīdzības principa neievērošanas aizliegums, konkrēti to attiecinot uz religiskās pārliecības brīvību, ir noteikts Reliǵisko organizāciju likuma 4. panta pirmajā daḷā, ka "tieša vai netieša iedzīvotāju tiesību ierobežošana vai priekšrocību radīšana iedzīvotājiem, kā arī jūtu aizskaršana vai naida celšana sakarā ar viṇu attieksmi pret religiju ir aizliegta. Par šā noteikuma pārkāpšanu vainīgās personas saucamas pie atbildības likumos noteiktajā kārtībā (Religisko organizāciju likums: Latvijas Republikas likums. Pieņemts 1995. gada 7. septembrī un spēkā no 1995. gada 10. oktobra. Latvijas Vēstnesis. 146(429), 26.09.1995.; Ziṇotājs, 02.11.1995.; 21.4. panta pirmā daḷa). Vienlīdzības principa neievērošanas aizliegums, konkrēti to attiecinot uz religiskās pārliecības brīvību darba tiesību jomā, nostiprināts Darba likuma 7. pantā, kurā cita starpā paredzēts, ka darbiniekiem ir vienlīdzīgas tiesības uz darbu, taisnīgiem, drošiem un veselībai nekaitīgiem darba apstākḷiem, kā arī uz taisnīgu darba samaksu bez jebkādas tiešas vai netiešas diskriminācijas - neatkarīgi no relig̣iskās pārliecības (Darba likums: Latvijas Republikas likums. Pieñemts 2001. gada 20. jūnijā un spēkā no 2002. gada 1. jūnija. Latvijas Vēstnesis. 105(2492), 06.07.2001.; Ziņotājs.15, 09.08.2001.; 15.7.pants). Par diskrimināciju rasu, nacionālās, etniskās vai reliğiskās piederības dēḷ vai par cita veida diskriminācijas aizlieguma pārkāpšanu atbildība paredzēta arī Krimināllikumā (Krimināllikums: Latvijas Republikas likums. Pieṇemts 1998. gada 17. jūnijā un spēkā no 1999. gada 1. aprīla. Latvijas Vēstnesis. 199/200, 08.07.1998.; Latvijas Republikas Saeimas un Ministru Kabineta Ziṇotājs. 1998, 15(149). 1. panta pirmā dal̦a). 
Laura Šāberte. Ārstniecības personas tiesības uz reliǵiskās pārliecības brīvību un to īstenošana, sniedzot veselības aprūpes pakalpojumus Latvijā: konstitucionālās aizsardzības ietvars

\section{Ārstniecības personas reliǵiskās pārliecības brīvības aizsardzïbas robežas Eiropas Cilvēktiesību tiesas interpretācijā}

Eiropas Cilvēktiesību tiesa ir atzinusi, ka religiskās pārliecības brīvība nav absolūta, un tā var tikt ierobežota, tiklīdz tai ir noteikta ietekme uz sabiedrību [11]. Analizēto jautājumu kontekstā ar Satversmes 99. pantu aizsargātā ārstniecības personas relig̣iskās pārliecības paušana (reliǵiskās pārliecības brīvības ārējā forma) atbilstoši Satversmes 116. pantam var tik ierobežota citu cilvēku tiesību, demokrātiskas valsts iekārtas, sabiedrības drošības, labklājibas un tikumïbas aizsardzības nolūkos [21, 116. pants]. Papildus, ievērojot starptautiskās saistības cilvēktiesību jomā, reliğiskās pārliecības paušana var tikt ierobežota arī sabiedriskās kārtības un veselības aizsardzības nolūkos $[29,18$. pants, kā arī 6., 9. pants].

Nosakot, vai noteiktais religíiskās pārliecības paušanas ierobežojums ir atzīstams par leg̣itīmu, ir nepieciešams izvērtēt:

1) vai tas ir noteikts ar likumu vai uz likuma pamata;

2) vai tam ir legitīms mērkis;

3) vai tas ir samērīgs [23].

Ja izvērtējuma rezultātā tiek atzìts, ka norma, kura noteic ierobežojumu religisisās pārliecības paušanai, neatbilst kaut vienam no nosauktajiem kritērijiem, ir atzīstams, ka šì norma neatbilst arī samērīguma principam un ir prettiesiska. Izšķiroša nozīme ir nevis tam, ka, nosakot aizliegumu, valsts formāli ir izpildījusi savus pozitīvos pienākumus reliǵijas brīvības efektīvas realizācijas jomā, bet gan tam, vai noteiktais ierobežojums ir tiesisks [23].

Tādējādi arī ārstniecības personas religiskās pārliecības brīvība, sniedzot veselības aprūpes pakalpojumus, nav absolūta un konstitucionālā līmenī ir ierobežojama, tiklīdz tai ir konkrēti pierādāma ietekme uz pacientiem vai citām personām ārstniecības iestādē.

Pierādāmās ietekmes uz sabiedrību kontekstā būtiska nozīme ir samērīguma izvērtēšanai [22]. Jāpierāda, ka ar ārstniecības personai noteiktās religisikās pārliecības paušanas ierobežojumu iecerētais legitīmais mērḳis tiks sasniegts, ka šo mērḳi nevar sasniegt ar mazāk ierobežojošiem alternatīviem līdzekḷiem un ka labums, ko iegūs pacienti vai citas personas ārstniecības iestādē, būs lielāks par ārstniecības personas tiesībām nodarīto kaitējumu, nosakot ierobežojumu. Piemēram, svarīgi ir pierādīt, ka ar aizliegumu ārstniecības personai nēsāt reliǵisko priekšmetu "krustiṇu" tiks novērsts pacienta veselības apdraudējums. Pierādī̌̌anas rezultātā jāiegūst apstiprinājums tam, ka pacienta veselības apdraudējumu nevar radīt citi priekšmeti, kuru nēsāšana, sniedzot veselības aprūpes pakalpojumus, ir atḷauta.

Eiropas Cilvēktiesību tiesas spriedumā lietā Eweida u. c. pret Apvienoto Karalisti ir atklāts, ka ārstniecības iestādei piemìt l̦oti plaša rīcības brīīiba, nosakot ārstniecības personai reliǵiskās pārliecības paušanas ierobežojumus ECPAK 9. pantā ietvertās cilvēka veselības aizsardzības kontekstā, un vienlaikus ir sniegts ieskats konkrēta pacientu 
Laura Šāberte. Ārstniecības personas tiesības uz religiskās pārliecības brīvību un to īstenošana, sniedzot veselības aprūpes pakalpojumus Latvijā: konstitucionālās aizsardzības ietvars

drošības aizsardzības kritērija pierādāmībā. Proti, ECPAK 9. pantā noteiktās tiesības uz religijias brīīibu nebūs pārkāptas, ja darba devējs medicīnas māsai liks noṇemt krustiṇu vai paslēpt to zem džempera ar augstu apkakli, gadījumā, ja tiks identificēts, ka pastāv risks pacienta vai pašas medicīnas māsas drošībai. Piemēram, pacients krustiṇu var satvert un noraut, ievainojot sevi un medicinas māsu, kā arī ja pastāv risks, ka ḳēiìte ar krustinu šūpojoties var skart atvērtu brūci. Darba devēja rīcībai, ierobežojot reliǵiskās pārliecības paušanu, vienmēr jābūt tiesiskai un konsekventai, un tā nevar būt absolūta, jo ir jāmeklē alternatīvi risinājumi, kā darbiniekam tomēr nodrošināt iespēju īstenot religisiskās pārliecības brīvību gadỉjumā, ja ierobežojumi tiek noteikti. Lietās, kas skar reliğiskās pārliecības paušanas ierobežošanu, primāri jāizvērtē visu iesaistīto pušu intereses, likumība un mērḳa leg̣itimitāte, kā arī samērīgums šì mērḳa sasniegšanai, lai noskaidrotu, vai nepastāv cilvēktiesību aizskāruma risks [11]. Pierādāmās ietekmes uz pacienta veselības apdraudējumu novērtēšanā, izlemjot par reliǵiskās pārliecības paušanas ierobežojumu noteikšanu ārstniecības personai, būtiska nozīme ir ne tikai ārstniecības iestādes pienākumam izvērtēt visu iesaistīto pušu intereses, likumību, iecerētā mērḳa legitimitāti un samērīgumu šì mērḳa sasniegšanai, bet arī ārstniecības iestādes pienākumam noteikt, vai ārstniecības personai ir iespējams piedāvāt alternatīvus risinājumus religískās pārliecības paušanai.

Kontekstā ar minētajām ECT atziṇām un pastāvošo tiesisko regulējumu veselības aprūpē Latvijā būtiski ir izpētìt, vai un kā ārstniecỉbas iestādēs Latvijā tiek ierobežota reliǵiskās pārliecības paušana un kādi alternatīvi risinājumi šādā gadījumā pastāv ārstniecības personu reliǵiskās pārliecības brīvības īstenošanas nodrošināšanai. Piemēram, viens no alternatīviem risinājumiem, ko ārstniecības iestāde var ārstniecības personai piedāvāt religiskās pārliecības paušanas ierobežošanas gadījumā, ir profesionālās veselỉbas aprūpes kapelāna ${ }^{6}$ garīgā aprūpe, ar ko jāsaprot morāls atbalsts un konsultāciju sniegšana religiskajos jautājumos $[25,2$. un 19. punkts]. Latvijas normatīvajos aktos šobrīd tiesības uz garīgo aprūpi veselības aprūpes procesā skaidri reglamentētas pacientiem un vinu tuviniekiem [26, 3. panta piektā daḷa]. Atseviškos normatīvajos aktos tiek paredzēts, ka profesionāli veselības aprūpes kapelāni veic ārstniecības iestāžu personāla garīgo aprūpi, sniedzot morālu atbalstu un nepieciešamās konsultācijas reliǵiskajos jautājumos atbilstoši normatīvajiem aktiem par ārstniecības atbalsta personu kompetenci ārstniecībā $[25,19$. punkts]. Tomēr šobrīd spēkā esošais normatīvais regulējums, kurš attiecināms uz ārstniecības personu tiesībām un to ìstenošanas kārtību veselības

${ }^{6}$ Profesionālais veselības aprūpes kapelāns ir ārstniecības atbalsta persona jeb persona, kurai nav tiesību nodarboties ar ārstniecību, bet kura ir tieši iesaistīta veselības aprūpes procesa nodrošināšanā (Ārstniecības likums: Latvijas Republikas likums. Pieṇemts 1997. gada 12. jūnijā un spēkā no 1997. gada 1. oktobra. Latvijas Vēstnesis. 167/168, 01.07.1997.; Latvijas Republikas Saeimas un Ministru Kabineta Zinotājs. 15, 1997, 1. panta 25. punkts; Ministru kabineta 2016. gada 24. maija noteikumi Nr. 317 "Ārstniecības personu un ārstniecības atbalsta personu reǵistra izveides, papildināšanas un uzturēšanas kārtība”. Latvijas Vēstnesis. 102(5674), 27.05.2016., OP numurs: 2016/102.2. 1. pielikuma 1.2. apakšpunkts, Nr. p. k. 9.). 
Laura Šāberte. Ārstniecības personas tiesības uz religigiskās pārliecības brīvību un to īstenošana, sniedzot veselības aprūpes pakalpojumus Latvijā: konstitucionālās aizsardzības ietvars

aprūpes procesā, raksturojams kā vispārīgs un tāds, kurš tiecas ārstniecības personu tiesības uz garīgo aprūpi Latvijas normatīvajos aktos atstāt vien cilvēka dabisko pamattiesību līmenī.

Pirmšķietami var secināt, ka pastāvošais tiesiskais regulējums l̦auj pacientam justies pārākam par ārstniecības personu tiesību uz relig̣iskās pārliecības brīvību īstenošanā. Tomēr tiesiskā regulējuma nenoteiktības tendences Latvijā var radìt arī gluži pretēju situāciju. Piemēram, PTL paredz pacientam tiesības zināt ārstējošo ārstu un citu veselības aprūpes procesā iesaistìto ārstniecības personu vārdu, uzvārdu, amatu, profesiju, specialitāti un kvalifikāciju [26, 4. panta otrā daḷa]. Šo tiesību ietvaros strīdus ābols ir ārstniecības personas identificējamība veselības aprūpes procesā gadījumā, ja ārstniecības persona nēsā seju pilnībā vai daḷēji aizsedzošu apgeērbu relig̣iskās pārliecības dēl (piemēram, burku, čadoru, nikābu). PTL neparedz pacienta tiesības papildus pārliecināties par ārstniecības personas identitāti pēc tam, kad ārstniecības persona ir atklājusi savu vārdu, uzvārdu, amatu, profesiju, specialitāti un kvalifikāciju [26, 4. panta otrā daḷ]. Tāpat vienlīdz aktuāls ir jautājums par komunikāciju un pacienta iespējām ìstenot savas tiesības saṇemt saprotamā formā informāciju par savu veselības stāvokli un veselỉbas aprūpes procesu [26, 4. panta piektā daḷa] apstākḷos, kad ārstniecības personas seja ir aizsegta.

Eiropas Cilvēktiesību tiesa lietas S.A.S. pret Franciju spriedumā, analizējot aizliegumu nēsāt seju aizsedzošu apgēērbu publiskās vietās Francijā, ir pievērsusies jautājumiem, kas skar komunikācijas apgrūtinājumu, nēsājot seju aizsedzošu apgeērbu. Šajā lietā ECT ir atzinusi, ka nav pamata noteikt pilnīgu seju aizsedzošu apgeērbu nēsāšanas aizliegumu publiskās vietās. Pilnīgs seju aizsedzoša apgeērba nēsāšanas aizliegums var būt nosakāms tikai gadījumos, ja pastāv vispārēji draudi sabiedrības drošībai valstiskā līmenī. Ja šādi noteikti draudi nepastāv, valsts var noteikt alternatīvus ierobežojošus lỉdzekḷus. Piemēram, personām atklāt sevi ar drošību saistītu iemeslu dēḷ vai tādēl, lai personu būtu iespējams identificēt. Nav nekādu pierādïjumu, kas ḷautu uzskatīt, ka sievietes, kuras nēsā pilnīgu sejas aizsegu, vēlas to izmantot l̦aunprātīgi. Cilvēka sejai ir būtiska nozīme sociālajā saskarsmē, un barjera pret citiem, kura tiek veidota, aizsedzot seju, pārkāpj citu personu tiesības dzīvot un socializēties vienotā sabiedrības telpā. Tieši apgrūtināta dzīvošana un socializēšanās vienotā sabiedrības telpā kontekstā ar cilvēka sejas aizklāšanu reliǵiskās pārliecības dẹḷ var tikt ḷaunprātīgi izmantota, un rezultātā personas, kas nēsā sejas aizsegu, tiesības var tikt nepamatoti ierobežotas [12].

Eiropas Cilvēktiesību tiesas apgalvojums, ka cilvēka sejai ir būtiska nozīme sociālajā saskarsmē un tā ir nozīmīga arī veselības pakalpojumu saṇemšanas procesā, ir vērā n,emams, tomēr ḷaunprātīga nodoma pierādišana lietās, kas skar reliǵiskās pārliecības paušanas ierobežošanu, var būt sarežğîta, jo bez konkrētiem pierādijjumiem nav pamata apgalvot, ka, nēsājot seju aizsedzošu apgeērbu, persona vēlas nodarīt kaitējumu apkārtējiem. Arī tiesnešu Nusbergeres un Jēderblūmas kopīgi paustajā un daḷēji atšḳirīgajā viedoklī par ECT spriedumu lietā S.A.S. pret Franciju izteikts viedoklis, ka patiesībai atbilst tas, ka sejai ir būtiska nozīme cilvēku savstarpējā saskarsmē. Taču šo ideju nedrīkst 
Laura Šāberte. Ārstniecības personas tiesības uz religigiskās pārliecības brīvību un to īstenošana, sniedzot veselības aprūpes pakalpojumus Latvijā: konstitucionālās aizsardzības ietvars

apvērst, secinot, ka cilvēku saskarsme nav iespējama gadījumā, ja seja nav atsegta. Par to liecina, piemēram, tādas nodarbes kā slēpošana vai motobraukšana, kurās tiek izmantotas seju pilnīgi aizsedzošas ḳiveres, un kostīmu nēsāšana karnevālu laikā. Neviens neapgalvos, ka šādās situācijās nav iespējams socializēties [12]. Arī pacienta aizsardzības nolūkos nedrīkst apgalvot, ka ārstniecības personas seju aizsedzoša apgeērba nēsāšana rada apdraudējumu pacientam, nepastāvot citiem pierādījumiem. Nevar kalpot par pamatojumu aizlieguma noteikšana ārstniecības personai nēsāt seju aizsedzošu religisko apgeérbu, vien dodot tikai vienu attaisnojumu, - ka nebūs iespējama savstarpējā saskarsme, jo tādējādi varētu tikt atzīts, ka religiskās pārliecības paušanas ierobežojums nav leǵitīms un ir pārkāpti Satversmes 116. panta nosacijumi.

Eiropas Cilvēktiesību tiesa spriedumā lietā Mirolubovs un citi pret Latviju norādījusi, ka ECPAK 9. pants uzliek valstij pienākumu būt neitrālai un objektīvai, pildot savas pārvaldes funkcijas religíijas lietās, un tas principā aizliedz jebkādu relig̣iskās ticības vai tās izteiksmes veidu likumības izvērtējumu [8]. Tāpat arī ECT spriedumā lietā Gatis Kovalkovs pret Latviju ir paudusi viedokli, ka tiesas uzdevums nav noteikt, kuri principi un uzskati pieteikuma iesniedzēja ticībā uzskatāmi par būtiskiem, vai iesaistìties jebkādā religisko jautājumu skaidrošanā [10]. Šajos spriedumos paustās atziṇas l̦auj secināt, ka svarīgi ir neitrāli izvērtēt pēc būtības nevis reliǵiskās pārliecības paušanas iespējamos ḷaunprātīgos nolūkus, bet gan līdzsvaru starp pacienta tiesībām, kuras varētu tikt apdraudētas, un ārstniecības personas pamattiesībām nēsāt šādu apgeeerbu. Šādu ECT atziṇu kontekstā Latvijas tiesiskā regulējuma veselības aprūpē turpmākajiem pētniecības virzieniem jābūt saistītiem ar normatīvā regulējuma pilnveidošanu saistībā ar ārstniecības personas identitātes atklāšanu pacienta veselības aizsardzības nolūkos, un tieši pierādāmās ietekmes uz pacienta drošību dēḷ, šis ir ārkārtīgi sarežğîti vērtējams jautājums.

Papildus minētajam, normatīvā regulējuma attīstības virzieniem jābūt saistītiem arī ar ārstniecỉbas personas un pacienta tiesību sabalansēšanu normatīvajos aktos. Latvijā nevienā normatīvajā aktā nav reglamentēts, ka pacienta pienākumos veselības aprūpes procesā ietilpst cienīt un respektēt ārstniecības personas tiesības un pamatbrīvības, rezultātā ārstniecības personas un pacienta religiskās pārliecības sadursme var rezultēties autonomijas aizskārumā.

Eiropas Cilvēktiesību tiesas spriedumā lietā Jehovahs's witnesses of Moscow and others vs. Russia ir atzinusi, ka ar ECAPK 9. pantu tiek aizsargāta personas autonomija gadījumā, ja jāizlemj jautājums par asins pārliešanu. Jehovas liecinieku atteikums pārliet asinis ir jautājums par indivīda personisko autonomiju, kas ir aizsargāta gan ar ECPAK 9. pantu, gan arī ar ECPAK 8. pantu, kas paredz arī privātās dzīves aizsardzību [9]. ECT šajā lietā norādīja, ka atteikšanās pārliet asinis nevar tikt pielīdzināta pašnāvībai, jo Jehovas liecinieki šajā gadījumā nebija atteikušies no ārstniecības kopumā. Asins pārliešana bija vienīgā medicīniskā procedūra, no kā viṇi bija atteikušies reliğiskās pārliecības dẹḷ. ECT šajā lietā atzina, ka pat tad, ja pacients atsakās no asins pārliešanas, kas pēc ārstniecības personas domām ir absolūta un būtiska vajadzība pacienta 
Laura Šāberte. Ārstniecības personas tiesības uz reliǵgiskās pārliecības brīvību un to īstenošana, sniedzot veselības aprūpes pakalpojumus Latvijā: konstitucionālās aizsardzības ietvars

dzīvības saglabāšanai vai neatgriezeniska kaitējuma viṇa veselībai novēršanai, privātās dzīves neaizskaramība un relig̣iskās pārliecības brīvība ḷauj pacientam pieñemt tādus lēmumus, kas var kaitēt un būt bīstami pacienta veselībai un dzìvībai. Šajā gadījumā ārstniecības personas iejaukšanās, pat tad, ja tā notikusi pacienta dzīvības vārdā, veicot asins pārliešanu, kurai pacients nav piekritis, būtu uzskatāma par ECPAK 9. panta un ECPAK 8. panta pārkāpumu [18].

Analizējot ārstniecības personas religiskās pārliecības brīivibas konstitucionālās aizsardzības robežas, turpmākajai pētniecībai paliek atvērts jautājums, vai ārstniecības personai Latvijā varētu tikt nodrošinātas tiesības atteikties no pacienta ārstniecības savas reliǵiskās pārliecības dẹl vai arī religíisko nesaskaṇu dēḷ ar pacientu? Tas varētu tikt attiecināts tikai uz tiem gadỉjumiem, kad pacienta dzīvība nav apdraudēta un ārstniecības iestādē pastāv alternatīvi šìs ārstniecības personas specialitātes risinājumi kvalitatīvai pacienta veselības aprūpei.

Latvijā PTL šobrīd tiek paredzēts, ka pacientam ir saistoši ārstniecības iestādes iekšèjās kārtības noteikumi un ārstniecības personas norādījumi $[26,15$. panta treša dalı]. Ja tie netiek pildīti, Ārstniecības likums paredz ārstam tiesības atteikties no turpmākās pacienta ārstēšanas, ja pacienta dzīvība nav apdraudēta, bet pacients neievēro noteikto režìmu, nepilda ārstniecības personu norādijumus vai apzināti kaitē savai veselỉbai un šādā veidā tieši ietekmē konkrētās slimības ārstēšanu [3, 42. pants]. Visām ārstniecības personām tiesības atteikties no turpmākas pacienta ārstēšanas nav paredzētas, tādas tiesības ir tikai ārstam. Šìs tiesības ir ekskluzīvas un saistītas ar ārsta profesionālo autonomiju [30, 188]. Tiesības atteikties no turpmākas pacienta ārstēšanas savas religiskās pārliecības dẹḷ ārstam vai citām ārstniecības personām normatīvajos aktos šobrīd nav noteiktas. Tomēr jautājums var kḷūt aktuāls, piemēram, ja ārstniecības persona pacientam ir devusi tādus norādījumus, kas galvenokārt balstās ārstniecỉbas personas religíiskajā pārliecībā, kura nav pretrunā ar vispārpieṇemtām medicīnas vadlīnijām, bet pacients šos norādījumus neievēro savas relig̣iskās pārliecỉbas dēḷ.

Pastāvošajos tiesiskajos apstākḷ̆os, kuros Latvijai pamattiesību ierobežošanas jomā nav gandrīz nekādas pieredzes [27, 704], ir visai sarežg̀iti noteikt ārstniecības personas reliğiskās pārliecības brīvības robežas, tāpēc ārstniecības personas reliǵiskās pārliecības konstitucionālajā aizsardzībā nepieciešams veikt papildu pētỉjumus. Turpmākie pētījumi ir nepieciešami arī tādẹl, lai ārstniecības iestāde, kas ir ārstniecības personas darba devējs, nosakot ierobežojumus ārstniecỉbas personas reliğiskās pārliecības paušanai, spētu novērst diskriminācijas aizlieguma pārkāpumus, kā arī normatīvajos aktos varētu atrast alternatīvus risinājumus religiskās pārliecības brīvības īstenošanas iespējām gadījumos, kad ierobežojumi ir noteikti. 
Laura Šāberte. Ārstniecības personas tiesības uz reliǵiskās pārliecības brīvību un to īstenošana, sniedzot veselības aprūpes pakalpojumus Latvijā: konstitucionālās aizsardzības ietvars

\section{Ārstniecības personas reliǵiskās pārliecības brīvības ìstenošanas iespējas darba devēja noteikto reliǵiskās pārliecības brīvības paušanas ierobežojumu kontekstā Eiropas Savienības Tiesas interpretācijā}

Būtiskas atziṇas par reliǵiskās pārliecības brīvības īstenošanas iespējām darbavietā, darba devēja noteikto reliǵgiskās pārliecības brīvības paušanas ierobežojumu kontekstā ir paudusi Eiropas Savienības Tiesa. Reliǵiskās pārliecības īstenošanu darbavietā EST ir analizējusi kontekstā ar izraudzīto līdzekḷu aizlieguma reliǵiskās pārliecības īstenošanai samērīgumu un iespējamu netiešas diskriminācijas kvalificēšanu, ja darba devējs nav apsvēris visus relig̣iskās pārliecības brīvības īstenošanas risinājumus. EST praksē paustās atziṇas par Direktīvā Nr. 2000/78/EK ietvertajām tiesību normām var būt nozīmīgs palīgs Latvijas veselības nozarē, nosakot, kā jāīsteno ārstniecības personas ar reliğisko pārliecību saistītās cilvēktiesības tās darbavietā, t. i., ārstniecības iestādē.

Eiropas Savienības Tiesa 2017. gada 14. marta spriedumā lietā Nr. C-157/15 ir analizējusi, vai aizliegums darba devēja iekšējos kārtības noteikumos islāmticīgai sievietei darbavietā nēsāt islāmisko lakatu nav tieša diskriminācija Direktīvas Nr. 2000/78/EK izpratnē, ja aizliegums darbavietā nēsāt ārējas politiskās, filozofiskās vai reliǵiskās pārliecības atšḳirības zīmes ir noteikts visiem darba n̦ēmējiem [17]. EST šajā spriedumā ir atzinusi, ka aizliegums nēsāt reliğiskās pārliecības atšḳirības zīmes darbavietā, nav tieša diskriminācija reliǵijas vai uzskatu dēl Direktīvas Nr. 2000/78/EK izpratnē, ja aizliegums tiek noteikts visiem uzṇēmuma darbiniekiem. Vienlaikus EST ir sniegusi tādu pamatojumu, kas var būt aktuāls arī ārstniecības personām veselības aprūpes pakalpojumu sniegšanas procesā Latvijā, proti, nosakot reliǵiskās pārliecības paušanas aizliegumu visiem darbiniekiem, respektējama ir darba devēja griba izrādīt neitralitāti pret klientiem. Neitralitātes politika ir saistīta ar Pamattiesību hartas 16. pantā atzīto darījumdarbības brīvību, un tai ir likumīgs raksturs. Visos gadījumos neitralitātes politika ir jāīsteno pareizi un sistemātiski, izvērtējot nepieciešamo attiecināmību uz pilnīgi visiem uzñēmuma darbiniekiem. Ierobežojumi, kas attiecināmi uz visiem sabiedrības darbiniekiem, ir jāiegrožo tikai līdz strikti nepieciešamajam līmenim. Pretējā gadījumā var tikt konstatēts diskriminācijas aizlieguma pārkāpums, ja tiek pierādīts, ka šḳietami neitrāls pienākums faktiski rada konkrētas nelabvēlīgas sekas. Direktīvas Nr. 2000/78/EK 1. pantā ietvertais jēdziens "relig̣ija" ir jāinterpretē tādējādi, ka tas ietver gan uzskatu pastāvēšanu (relig̣iskās pārliecības brīvības iekšējais aspekts), gan reliǵijas paušanu (religískās pārliecības brīvības ārējais aspekts) [17].

\footnotetext{
Eiropas Savienības Tiesas 2017. gada 14. marta spriedums lietā C-157/15 par lūgumu sniegt prejudiciālu nolēmumu atbilstoši LESD 267. pantam, ko Hof van Cassatie (kasācijas tiesa, Beḷgija) iesniedza ar lēmumu, kas pieṇemts 2015. gada 9. martā un tiesā reǵistrēts 2015. gada 3. aprīlī, tiesvedībā Samira Achbita, Centrum voor gelijkheid van kansen en voor racismebestrijding pret G4S Secure Solutions NV.
} 
Laura Šāberte. Ārstniecības personas tiesības uz religiskās pārliecības brīvību un to īstenošana, sniedzot veselības aprūpes pakalpojumus Latvijā: konstitucionālās aizsardzības ietvars

Papildu viedoklis atrodams EST 2016. gada 31. maija spriedumā lietā Nr. C-157/15 [16], kurā analizēts, vai privāts darba devējs drīkst aizliegt nēsāt ārējas politiskās, filozofiskās vai reliǵiskās pārliecības atšḳirības zīmes darbavietā un vai viṇš drīkst atlaist darbiniekus, ja tas netiek ievērots. EST šajā lietā ir atzinusi, ka vienmēr jāpārbauda, vai mērḳis varēja tikt sasniegts ar mazāk ierobežojošiem līdzekliiem nekā formālu aizliegumu. Piemēram, pirms noteikt pilnīgu aizliegumu, jāapsver iespēja norīkot darbiniekus darbā ar tādiem klientiem, kuri neiebilst pret redzamām un uzkrītošām reliğiskās pārliecības atšķirības zīmēm. Būtiska ir samērīguma principa ievērošana uzṇēmuma neitralitātes politikas ieviešanā attiecībā uz visiem darbiniekiem. Nosakot reliǵiskās pārliecības paušanas ierobežojumus līdz strikti nepieciešamajam līmenim, jāṇem vērā, cik liela un uzkrītoša ir katra konkrētā darbinieka reliǵiskās atšḳirības zīme, kā arī darbinieka pienākumu būtība, konteksts, kurā darbiniekam jāizpilda šie pienākumi, kā arī attiecīgās dalībvalsts nacionālā identitāte [16].

Samērīguma ievērošanas nepieciešamība attiecībā uz reliǵiskās pārliecības brīvības paušanas ierobežojumiem uzsvērta arī EST 2016. gada 13. jūlija spriedumā lietā Nr. C-188/15 [15], kurā pēc būtības analizēts jautājums, vai Direktīvas Nr. 2000/78/EK 4. panta 1. punkts ir interpretējams tādējādi, ka darba devēja griba n̦emt vērā klienta vēlmi vairs nesaṇemt minētā darba devēja pakalpojumus, ko sniedz darbiniece, kura nēsā islāmisko lakatu, var būt izšḳiroša prasība, lai noteiktu aizliegumu darbiniecei šo lakatu nēsāt [29]. Šajā spriedumā EST ir atzinusi, lai uzṇēmuma noteiktais aizliegums reliǵiskās pārliecības īstenošanai nebūtu kvalificējams kā netieša diskriminācija, tam jābūt attaisnotam ar likumīgu mērḳi un jāpierāda, ka izmantotie līdzekḷi šĩ mērḳa sasniegšanai ir piemēroti un vajadzīgi. Ja tiek konstatēts, ka darbiniekiem tiek radītas nelabvēlīgas sekas, tad jāsecina, ka pastāv atšḳirīga attieksme [15].

Eiropas Savienības Tiesas interpretācija religiskās pārliecības brīvības īstenošanas iespēju darba devēja noteikto religiskās pārliecības brīvības paušanas ierobežojumu kontekstā pamatojusi arī ar ECT judikatūru - rakstā iepriekš minēto spriedumu lietā Eweida u. c. pret Apvienoto Karalisti [17]. Proti, lai novērstu, ka darbiniekam tiek radītas nelabvēlīgas sekas, nosakot striktas religíiskās pārliecības īstenošanas robežas, ārstniecības iestādes pienākums ir vērtēt samērīgumu, nosakot, vai ierobežojums ir strikti nepieciešams un atbilstošs, vai ar to var sasniegt legitīmu mērḳi un vai paredzēto mērḳi nevar sasniegt ar citiem līdzekḷiem, kā arī vai pastāv alternatīvi risinājumi, kā ārstniecības persona tomēr var īstenot reliǵiskās pārliecības brīvību.

Rezumējot šeit apkopotās atziņas, var teikt, ka cilvēka pamattiesību nepamatota ierobežošana ir pirmais brīdinājuma signāls, kas liecina par varas antidemokrātisko raksturu. Neviens ierobežojums nedrīkst aizskart pamattiesību būtību, kā arī nevar tikt noteikts lielākā apjomā nekā objektīvi ir nepieciešams [27, 704]. Relig̣iskās pārliecības brīvības īstenošana darbavietā ir sistēmiski jāsamēro ar darba pienākumu nozīmi un darbinieku skaitu, kuri vēlas paust reliǵisko pārliecību. Ārstniecības iestādei, lai novērstu diskriminācijas aizlieguma pārkāpumus ārstniecības personas reliǵiskās pārliecības īstenošanas jomā, būtu jāapsver, kādi alternatīvi risinājumi pastāv gadỉjumā, 
Laura Šāberte. Ārstniecības personas tiesības uz reliǵiskās pārliecības brīvību un to īstenošana, sniedzot veselības aprūpes pakalpojumus Latvijā: konstitucionālās aizsardzības ietvars

ja tiek noteikts religiskās pārliecības paušanas ierobežojums. Piemēram, jāpadomā par iespēju nodrošināt profesionālā veselības aprūpes kapelāna atbalstu, vai arī iespēju nodrošināt ārstniecības personai tiesības atteikties no pacienta turpmākās ārstēšanas relig̣iskās pārliecības dēl, ja pacienta dzīvība nav apdraudēta un ārstniecības iestādē ir cita ārstniecības persona, kas var sniegt līdzvērtīgu veselības aprūpi. Ievērojot ārstniecības personas izvēles brīvības veselības aprūpē ierobežojumus attiecībā uz tiesībām atteikties no pacieta ārstniecības Latvijā, ārstniecības iestādei papildus būtu jāapsver, vai, ierobežojot reliǵiskās pārliecības brīvības paušanu, nevar tikt nepamatoti ierobežota ārstniecības personas iekšèjā ticība jeb religíiskās pārliecības brīivibas iekšējais aspekts. Ārstniecības iestādei vienmēr jāpārbauda, vai iecerētais mērḳis var tikt sasniegts ar mazāk ierobežojošiem līdzekḷiem nekā formālu aizliegumu, un tādējādi jātiecas nodrošināt reliǵiskās pārliecības brīvības īstenošanu tiktāl, ciktāl tas vien iespējams. Nav piel̦aujama ārstniecības personas relig̣iskās pārliecības brīvības formāla ierobežošana.

\section{Secinājumi}

No ārstniecības personas tiesību uz religíiskās pārliecības brīvību konstitucionālās aizsardzības satura izpētes izriet trīs svarīgi secinājumi:

1. Ārstniecības personas reliǵiskās pārliecības brīiības, sniedzot veselības aprūpes pakalpojumus, konstitucionālā aizsardzība nav absolūta, un tā ir ierobežojama, tiklīdz tai ir konkrēti pierādāma ietekme uz pacientiem vai citām personām ārstniecības iestādē.

2. Ārstniecības iestādei kā ārstniecības personas darba devējam ir l̦oti plaša rīcības brīvība reliǵiskās pārliecības brīvības ierobežojumu noteikšanai, jo īpaši veselības aizsardzības nolūkos. Pastāvošās tiesiskās nenoteiktības apstākḷos ārstniecības personas un pacienta reliǵiskās pārliecības brīvības tiesiskās sabalansētības izvērtējums saskaṇā ar Latvijas normatīvo regulējumu pacientu tiesību jomā var būt kontroversiāls.

3. Par rakstā izzinātajiem problēmjautājumiem nepieciešams veikt turpmākus padziḷinātus pētījumus, lai attīstītu ārstniecības personu tiesību aizsardzību Latvijā. Pētniecības ietvaros nepieciešams izzināt, kā veselības aprūpes nozarē Latvijā relig̣iskās pārliecības brīvību īstenot sabalansēti, neaizskarot ne ārstniecības personu, ne pacientu, un ciktāl religíiskās pārliecības brīvība ir savienojama ar ārstniecības personas profesionālo darbību un tās unikalitāti pacientu tiesību kontekstā.

Šo jautājumu kontekstā turpmāk nepieciešams pētīt šādus aspektus:

- tiesības atteikties no pacienta ārstniecības;

- tiesības uz garīgo aprūpi;

- pienākumu cienìt un respektēt ārstniecības personas tiesības un pamatbrīvības;

- aizliegumu sodìt vai radīt nelabvēlīgus apstākḷus ārstniecības personai, kura aizstāv savas tiesības un pamatbrīvības; 
Laura Šāberte. Ārstniecības personas tiesības uz reliǵiskās pārliecības brīvību un to īstenošana, sniedzot veselības aprūpes pakalpojumus Latvijā: konstitucionālās aizsardzības ietvars

- ārstniecības personas atpazīstamības robežas veselības aprūpes procesā;

- religisikās pārliecības paušanas ierobežošanu Latvijas ārstniecības iestādēs.

Turpmākajos pētījumos nepieciešams izzināt arī citus juridiskai diskusijai atvērtus jautājumus, piemēram, vai, ierobežojot ārstniecības personas religíiskās pārliecības brīvību tās ārējā aspektā (forum externum), netiek aizskarts šīs brīiības iekšējais aspekts (forum internum), ievērojot šo aspektu mijiedarbību un ārstniecības personas izvēles brīvības veselības aprūpē ierobežojumus.

\section{Pateicība}

Autore izsaka pateicību LL.D. Santai Slokenbergai par padomu un atbalstu raksta izstrādes gaitā.

\section{Medical Practitioners Right to Freedom of Religion when Providing Health Care Services in the Republic of Latvia. Constitutional Protection Framework}

\section{Abstract}

The article presents constitutional protection of medical practitioner's right to freedom of religion in the context of the Republic of Latvia international obligations.

The author of the article has studied the content of Article 99 of the Constitution of the Republic of Latvia that reveals medical practitioner's right to freedom of religion constitutional protection. To explore medical practitioner's right to freedom of religion boundaries, when providing health-care services, the author of the article has analysed the European Court of Human Rights and the Court of Justice of the European Union case law. In order to develop a medical practitioner's rights in the Republic of Latvia Author of the article points the further necessary research directions.

Keywords: medical practitioner, patient, health care, health services, freedom of religion, constitutional protection.

\section{Literatūra}

1. Administratīvās apgabaltiesas 2011. gada 2. decembra spriedums lietā Nr. A42446907(AA43-3 165-11/18).

2. Apvienoto Nāciju Organizācijas Vispārējā cilvēktiesību deklarācija, 10.12.1948.

3. Ārstniecības likums: Latvijas Republikas likums: pieṇemts 12.06.1997. un spēkā no 01.10.1997. Latvijas Vēstnesis. 167/168, 01.07.1997.; Latvijas Republikas Saeimas un Ministru kabineta Ziñotājs. 15, 1997. 
Laura Šāberte. Ārstniecības personas tiesības uz religiskās pārliecības brīvību un to īstenošana, sniedzot veselības aprūpes pakalpojumus Latvijā: konstitucionālās aizsardzības ietvars

4. Balodis, R. Baznīcu tiesības. Rīga: Religijas brīvības asociācija, 2002.

5. Balodis, R. Satversmes 99. panta komentāri. No: Latvijas Republikas Satversmes komentāri. VIII nodaḷa. Cilvēka pamattiesības. Autoru kolektīvs R. Baloža zinātniskajā vadībā. Rīga: Latvijas Vēstnesis, 2011.

6. Eiropas Cilvēka tiesību un pamatbrīvību aizsardzības konvencija: starptautisks dokuments: pien,emts 1950. gada 04. novembrī un Latvijā spēkā no 1997. gada 27. jūnija. Latvijas Vēstnesis. 143/144, 13.06.2007.

7. Eiropas Cilvēktiesību tiesas 2007. gada 12. aprīḷa spriedums lietā Ivanova vs. Bulgaria, pieteikuma Nr. 52435/99.

8. Eiropas Cilvēktiesību tiesas 2009. gada 15. septembra spriedums lietā Miroḷubovs un citi pret Latviju, pieteikuma Nr. 798/05.

9. Eiropas Cilvēktiesību tiesas 2010. gada 10. jūnija spriedums lietā Jehovahs's witnesses of Moscow and others vs. Russia, pieteikuma Nr. 302/02.

10. Eiropas Cilvēktiesību tiesas 2012. gada 31. janvāra spriedums lietā Gatis Kovaḷkovs pret Latviju, pieteikuma Nr. 35021/05.

11. Eiropas Cilvēktiesību tiesas 2013. gada 15. janvāra spriedums lietā Eweida and Others vs. the United Kingdom, pieteikuma Nr. 48420/10, 59842/10, 51671/10 un 36516/10.

12. Eiropas Cilvēktiesību tiesas 2014. gada 1. jūlija spriedums lietā S.A.S. pret Franciju, pieteikuma Nr. 43835/11.

13. Eiropas Savienības Padomes 2000. gada 27. novembra Direktīva 2000/78/EK, ar ko nosaka kopēju sistēmu vienlīdzīgai attieksmei pret nodarbinātību un profesiju.

14. Eiropas Savienības Pamattiesību Harta. Eiropas Savienības Oficiālais Vēstnesis. 2012/C, 326/02.

15. Eiropas Savienības Tiesas 2016. gada 13. jūlija spriedums lietā C-188/15 Asma Bougnaoui, Association de défense des droits de l'homme (ADDH) pret Micropole SA (Cour de cassation. (Kasācijas tiesa, Francija - lūgums sniegt prejudiciālu nolēmumu).

16. Eiropas Savienības Tiesas 2016. gada 31. maija spriedums lietā C-157/15. Samira Achbita un Centrum voor gelijkheid van kansen en voor racismebestrijding pret G4S Secure Solutions NV (Hof van Cassatie).

17. Eiropas Savienības Tiesas 2017. gada 14. marta spriedums lietā C-157/15: pieṇemts 2015. gada 9. martā un tiesā reǵistrēts 2015. gada 3. aprīlī, tiesvedībā Samira Achbita, Centrum voor gelijkheid van kansen en voor racismebestrijding pret G4S Secure Solutions NV.

18. European Court of Human Rights. Guide to Article 9. Freedom of thought, conscience and religion.

19. Latviešu valodas vārdnīca. Spektors, A. Mākslīgā intelekta laboratorija 2009-2017. Iegūts no: http://www.tezaurs.lv [sk. 15.04.2017.].

20. Latvijas Republikas Augstākās tiesas Administratīvo lietu departamenta 2010. gada 6. maija spriedums lietā Nr. A42446907 (SKA-160/2010).

21. Latvijas Republikas Satversme: LV likums: pieṇemts 15.02.1922. un spēkā no 07.11.1922. Likumu un noteikumu kräjums. 12, 1922.; Latvijas Vēstnesis. 43, 01.07.1993.; Latvijas Republikas Saeimas un Ministru Kabineta Ziñotājs. 6, 2004.

22. Latvijas Republikas Satversmes tiesas 2002. gada 22. oktobra spriedums lietā Nr. 2002-04-03.

23. Latvijas Republikas Satversmes tiesas 2011. gada 18. marta spriedumu lietā Nr. 2010-50-03.

24. Latvijas Republikas Satversmes tiesas tiesnešu Sanitas Osipovas un Inetas Ziemeles atsevišksās domas lietā Nr. 2015-19-01 "Par Kriminālprocesa likuma 657. panta pirmās, trešās un piektās dạ̦as atbilstību Latvijas Republikas Satversmes 92. panta pirmajam teikumam”. Rīga, 2016. gada 13. maijs. 
Laura Šāberte. Ārstniecības personas tiesības uz reliǵiskās pārliecības brīvību un to īstenošana, sniedzot veselības aprūpes pakalpojumus Latvijā: konstitucionālās aizsardzības ietvars

25. Ministru kabineta noteikumi Nr. 134 “Noteikumi par kapelānu dienestu”: pieṇemti 15.02.2011. un spēkā no 26.02.2011. Latvijas Vēstnesis. 32 (4430), 25.02.2011.

26. Pacientu tiesību likums: Latvijas Republikas likums: pieṇemts 17.12.2009. un spēkā no 01.03.2010. Latvijas Vēstnesis. 205(4191), 30.12.2009.

27. Pleps, J., Pastars, E., Plakane, I. Konstitucionālās tiesības. Rīga: Latvijas Vēstnesis, 2004.

28. Renucci, J. F. Article 9 of the European Convention on Human Rights. Freedom of Thought, Conscience and Religion. Council of Europe, 2005.

29. Starptautiskais pakts par pilsoṇu un politiskajām tiesībām: starptautisks dokuments: pieṇemts 1966. gada 16. decembrī un Latvijā spēkā no 1992. gada 14. aprīḷa. Latvijas Vèstnesis. 61, 23.04.2003.

30. Šāberte, L. Ārstniecības personas. No: Medicīnas tiesības. Autoru kolektīvs S. AšnevicasSlokenbergas zinātniskajā redakcijā. Rīga: Tiesu namu aǵentūra, 2015.

31. Vispārējā cilvēktiesību deklarācija: pieņemta un pasludināta ar Apvienoto Nāciju Organizācijas Ģenerālās Asamblejas 1948. gada 10. decembra 217. A (III) rezolūciju. 